\title{
Erythropoietin Prevents Haloperidol Treatment-Induced Neuronal Apoptosis through Regulation of BDNF
}

\author{
Anilkumar Pillai*, ${ }^{1,2}$, Krishnan M Dhandapani ${ }^{3}$, Bindu A Pillai ${ }^{1,2}$, Alvin V Terry $\mathrm{Jr}^{4}$ and \\ Sahebarao P Mahadik',2 \\ 'Department of Psychiatry and Health Behavior, Medical College of Georgia, Augusta, GA, USA; ${ }^{2}$ Medical Research Service Line, Veterans Affairs \\ Medical Center, Augusta, GA, USA; ${ }^{3}$ Department of Neurosurgery, Medical College of Georgia, Augusta, GA, USA; ${ }^{4}$ Department of Pharmacology \\ and Toxicology, Medical College of Georgia, Augusta, GA, USA
}

Functional alterations in the neurotrophin, brain-derived neurotrophic factor (BDNF) have recently been implicated in the pathophysiology of schizophrenia. Furthermore, animal studies have indicated that several antipsychotic drugs have time-dependent (and differential) effects on BDNF levels in the brain. For example, our previous studies in rats indicated that chronic treatment with the conventional antipsychotic, haloperidol, was associated with decreases in BDNF (and other neurotrophins) in the brain as well as deficits in cognitive function (an especially important consideration for the therapeutics of schizophrenia). Additional studies indicate that haloperidol has other deleterious effects on the brain (eg increased apoptosis). Despite such limitations, haloperidol remains one of the more commonly prescribed antipsychotic agents worldwide due to its efficacy for the positive symptoms of schizophrenia and its low cost. Interestingly, the hematopoietic hormone, erythropoietin, in its recombinant human form rhEPO has been reported to increase the expression of BDNF in neuronal tissues and to have neuroprotective effects. Such observations provided the impetus for us to investigate in the present study whether co-treatment of rhEPO with haloperidol could sustain the normal levels of BDNF in vivo in rats and in vitro in cortical neuronal cultures and further, whether BDNF could prevent haloperidol-induced apoptosis through the regulation of key apoptotic/antiapoptotic markers. The results indicated that rhEPO prevented the haloperidol-induced reduction in BDNF in both in vivo and in vitro experimental conditions. The sustained levels of BDNF in rats with rhEPO prevented the haloperidol-induced increase in caspase-3 $(p<0.05)$ and decrease in $\mathrm{Bcl}-\mathrm{xl}(p<0.0 \mathrm{I})$ protein levels. Similarly, in vitro experiments showed that rhEPO prevented $(p<0.00 \mathrm{I})$ the haloperidol-induced neuronal cell death as well as the decrease in $\mathrm{Bcl}-\mathrm{xl}$ levels $(p<0.0 \mathrm{I})$. These findings may have significant implications for the development of neuroprotective strategies to improve clinical outcomes when antipsychotic drugs are used chronically.

Neuropsychopharmacology (2008) 33, 1942-195I; doi: I0.1038/sj.npp. I 30I566; published online 5 September 2007

Keywords: antipsychotics; haloperidol; erythropoietin; neuroprotection; schizophrenia

\section{INTRODUCTION}

The prevention and/or amelioration of the neuropathological events in schizophrenia is a major therapeutic objective, however, an equally important goal is to ensure that the major therapeutic agents used (ie the antipsychotics) do not exacerbate this pathology. The effects of typical antipsychotics have been compared to atypical antipsychotics on psychopathology and neuropathology in schizophrenia, and based on short-term studies; atypical antipsychotics have been suggested to have a more favorable profile (Lieberman et al, 2003; Jarskog and Lieberman, 2006; Kapur et al, 2005;

*Correspondence: Dr A Pillai, Department of Psychiatry and Health Behavior, Medical College of Georgia, Medical Research Service (242), Veterans Affairs Medical Center, 5B-103, I Freedom Way, Augusta, GA 30904, USA, Tel: + I 7067330188 ext. 249|, Fax: + I 706823 3949, E-mail: apillai@mail.mcg.edu

Received 8 March 2007; revised I 4 July 2007; accepted 8 August 2007
Leucht et al, 2005). However, several animal studies indicate that long-term exposure to both classes of antipsychotics can be associated with adverse neurochemical and cognitive effects (reviewed, Terry and Mahadik, 2007). In addition, the large prospective clinical study, Clinical Antipsychotic Trials of Intervention Effectiveness (CATIE) indicated few significant advantages of typical antipsychotics over the representative conventional agent, perphenazine, when dropout rates (ostensibly due to intolerable side effects, lack of efficacy, etc) were considered. Further analyses of CATIE results indicated no significant difference between the two antipsychotic classes on psychosocial functioning in patients with chronic schizophrenia (Swartz et al, 2007).

A growing area of investigation within the field of schizophrenia research is the role of neurotrophins in the both pathophysiology and therapeutics of the illness. For example, deficits in brain-derived neurotrophic factor (BDNF) signaling have been implicated in the pathogenesis of schizophrenia (reviewed by Shoval and Weizman, 2005; 
Buckley et al, 2007) as having elevations of apoptotic proteins (eg proapoptotic triggers) that may result from alterations in neurotrophins. The support for this hypothesis is based upon reports of significant alterations of the proteins Bcl-2 and Bax (specifically the Bax/Bcl-2 ratio) in brain regions that are known to be important to the symptomatology of the schizophrenia, such as temporal cortex (Jarskog et al, 2004). Interestingly, short-term rodent studies have indicated an upregulation of antiapoptotic markers following treatment with olanzapine and clozapine (He et al, 2004; Bai et al, 2004), but showed increased activation of caspase-3, an apoptotic marker, with chronic use of both typical and atypical antipsychotics (Jarskog et al, 2007). Other studies in rodents have indicated that typical and atypical antipsychotics can have favorable or unfavorable effects on brain levels of BDNF (and other neurotrophins such as nerve growth factor) depending on the length of treatment (Alleva et al, 1996; Parikh et al, 2004a, b, c; Pillai et al, 2006; reviewed by Terry and Mahadik, 2007).

Among the various antipsychotics, haloperidol (HAL, a conventional or typical agent) continues to be widely prescribed worldwide due to higher potency and lower cost compared to many other antipsychotics, despite the possibility of adverse side effects. In addition, it appears to be among the least desirable agents from the standpoint of its temporal effects on neurotrophins in the brain (see Terry and Mahadik, 2007). Accordingly, we have developed the hypothesis that the adjunctive use of neurotrophic compounds might provide neuroprotective effects and limit the adverse side effects associated with drugs like HAL. The direct delivery of neurotrophins (themselves) like BDNF to the brain remains a major challenge, however, due to permeability of the blood-brain barrier. An alternative approach to directly administering BDNF is to increase BDNF activity in the brain by agents that can easily enter in the CNS. Interestingly, recombinant human EPO (rhEPO) treatment has recently been reported to have such effects (ie to increase the expression of BDNF in the brain; Zhang et al, 2006). Furthermore, several studies have shown that rhEPO is a potent neuroprotective agent against neural dysfunction resulting from a variety of neural insults that involve increased apoptosis (Sakanaka et al, 1998; Siren et al, 2001a; Dzietko et al, 2004; Spandou et al, 2004).

The expression of erythropoietin (EPO) and its receptors have also been shown in cultured neurons and astrocytes in vitro, and rhEPO has been found to be neuroprotective in a variety of situations, including hypoxia and oxidative stress in vivo (Bernaudin et al, 1999, 2000; Brines et al, 2000; Siren et al, 2001b; Marti, 2004). Furthermore, a recent study by Ehrenreich et al, 2007 has shown that rhEPO improves cognitive functions in chronic schizophrenic patients. We recently reported that HAL and olanzapine have distinct temporal effects on the expression of EPO and its receptor in adult rat brain (Pillai and Mahadik, 2006). Our data indicated that 14 days of HAL treatment increased the levels of EPO and its receptor in hippocampus and striatum, but their levels decreased below control values by 45 days of treatment, whereas olanzapine treatment sustained their increased levels at 45 days. These changes were in parallel to the neuropathological changes reported earlier in rats (Mahadik et al, 1988; Terry et al, 2002, 2003). These studies strongly indicate that rhEPO may prevent HAL-induced reduction in BDNF levels in the brain and thus allow BDNF to provide neuroprotection through apoptotic regulation. Such animal data provide an initial proof of concept for the potential use of rhEPO as an adjunctive approach to combat adverse effects of chronic antipsychotic therapy in human patients.

In the present study, co-treatment of rhEPO with HAL was studied to determine effects on the levels of BDNF in both in vivo and in vitro experiments. We also determined whether changes in BDNF levels after HAL alone or cotreatment with rhEPO were associated with changes in various apoptotic markers (Bcl-2, Bcl-xl, Bax, and caspase-3).

\section{MATERIALS AND METHODS}

\section{Animals}

All in vivo experiments were conducted in adult male albino rats (Harlan Sprague-Dawley Inc., Indianapolis, IN, USA) weighing $225-250 \mathrm{~g}$. All in vitro experiments were done in cerebral cortical neuronal cultures from embryonic day 15 mouse fetuses. Animal use procedures were performed after being reviewed and approved by Medical College of Georgia Committee on Animal Use for Research and Veterans Affairs Medical Center Subcommittee on Animal Use. Procedures were consistent with AAALAC guidelines as per Public Health Service Policy on Humane Care and Use of Laboratory Animals.

\section{Drug Treatments in Rats}

Animals were housed one per cage under a 12-h light/12-h dark cycle and at constant temperature $\left(25^{\circ} \mathrm{C}\right)$ and humidity. They were allowed free access to food and water. Haloperidol (Sigma Chemical Company, St Louis, MO) was dissolved in $0.1 \mathrm{M}$ acetic acid and subsequently diluted daily $(1: 100)$ with tap water to administer the final daily dose of drug (diluted drug solution replaced drinking water). The amount of drug intake was measured daily, and adjustments were made depending upon the fluid consumed and weight of the animals. This method was preferred over multiple intramuscular injections to maintain more constant drug levels and to reduce stress and neuromuscular damage. Rats ( $N=6-8$ per group) were administered HAL, HAL and rhEPO, or vehicle for 6 weeks. The HAL dose $(2.0 \mathrm{mg} / \mathrm{kg} /$ day) was selected based on previous studies where this dose was found to establish clinically relevant (Baldessarini et al, 1988) steady-state plasma levels in the rat (Terry et al, 2007). This dose is also comparable to the optimal dose to cause pharmacological effects (Skarsfeldt, 1996; Didriksen, 1995; Bymaster et al, 1996). The schedule of HAL administration was selected based on several studies by us and others in which differences in behavioral as well as pharmacological effects were seen after 45 days of treatment in rats (Parikh et al, 2004a, b, c; Terry et al, 2004; Pillai et al, 2005; Angelucci et al, 2000; Dawson et al, 2001). rhEPO (500 U/kg; Epoetin alfa, Eprex, Cilag) was administered intraperitoneally three times per week for 6 weeks. Tap water containing $0.1 \mathrm{M}$ acetic acid was used for control group to assure that unanticipated effect of the vehicle was not present. All animals were monitored for change in body 
weight and food intake as possible adverse effects of the treatment.

\section{Tissue Sample Preparation}

At the end of treatment, rats were killed by decapitation, and the anterior right medial cortex from experimental and control rats were separately dissected and homogenized in ice-cold buffer ( $10 \mathrm{mM}$ Tris- $\mathrm{HCl}, \mathrm{pH} 7.5,150 \mathrm{mM} \mathrm{NaCl}$, $0.1 \%$ SDS, $1 \%$ Nonidet P- 40 , and $1 \%$ sodium deoxycholate) supplemented with protease inhibitor cocktail (Sigma) containing $104 \mathrm{mM}$ AEBSF, $0.08 \mathrm{mM}$ aprotinin, $2 \mathrm{mM}$ leupeptin, $4 \mathrm{mM}$ bestatin, $1.5 \mathrm{mM}$ pepstatin $\mathrm{A}$, and $1.4 \mathrm{mM}$ E-64. After 15-min incubation period on ice, the extracts were clarified by centrifugation at 14000 r.p.m. for $15 \mathrm{~min}$ at $4{ }^{\circ} \mathrm{C}$ and stored at $-70^{\circ} \mathrm{C}$. Protein concentrations were determined by the bicinchoninic acid (BCA Protein Assay Kit, Sigma).

\section{Brain-Derived Neurotrophic Factor Immunoassay}

Brain-derived neurotrophic factor protein was measured with a conventional sandwich ELISA using the BDNF Emax ImmunoAssay System (Promega, Madison, WI, USA) according to the protocol of the manufacturer.

\section{In Vitro Experiments}

All cell-culture reagents, sera, and media were obtained from Invitrogen (Carlsbad, CA, USA).

\section{Cerebral Cortical Neuronal Cultures}

Mouse cortical neurons were cultured as described previously (Dhandapani et al, 2003). Briefly, cerebral cortices from CD-1 murine embryos (E15) were aseptically dissected and plated at $3.5 \times 10^{5}$ cells per well on polyethyleneiminecoated 24-well plates. Neurons were cultured in Neurobasal medium supplemented with B27, $2 \mathrm{mM}$ L-glutamine, and antibiotics (Invitrogen). On the third day in vitro (DIV3), media was replaced with Neurobasal supplemented with B27 minus antioxidants, glutamine, and antibiotics. Purified neuronal cultures were routinely $>97 \%$ neurons, as assessed by MAP-2 immunostaining. Neurons were used for treatments between DIV 5 and 7.

\section{Drug Treatments of Cortical Neurons in Culture}

The optimum dose and time of exposure of rat cortical neurons to HAL was determined by treating neurons with various concentrations of HAL $(10,20,40,80$, and $100 \mu \mathrm{M})$ for different time periods $(6,12,24$, and $48 \mathrm{~h})$. Neuroprotective experiments were done using $30 \mathrm{pM}$ rhEPO and $50 \mu \mathrm{M} \mathrm{HAL}$ as the optimum dose. Cells were pretreated with rhEPO for $24 \mathrm{~h}$ and then continued either on rhEPO (EPO) or on rhEPO plus HAL (co-treatment, EPO + HAL) for the next $24 \mathrm{~h}$. Cells were then harvested for either cell viability assay or for analysis of BDNF and apoptotic proteins. Each treatment was done in four wells, and each experiment was repeated three times by independent investigators.

\section{Determination of Neuronal Cell Viability in Culture}

Neuronal cell viability in culture was assessed using the 3(4,5-dimethylthiazol-2-yl)-2,5-diphenyltetrazolium bromide (MTT) reduction assay, as described by Dhandapani et al (2003). Briefly, following treatments, MTT $(5 \mathrm{mg} / \mathrm{ml}$ in phenol red-free RPMI-1640) was added to each well for $4 \mathrm{~h}$ at $37^{\circ} \mathrm{C}$. Following incubation, formazan salts were dissolved in acidic isopropanol and absorbance was measured using a Synergy HT plate reader (Bio-Tek, Winooski, VT) at $570 \mathrm{~nm}$ using a reference wavelength of $900 \mathrm{~nm}$. All readings were compared with the control treatment group, which represented $100 \%$ viability.

\section{Immunostaining for Neuronal Morphology with MAP-2 Antibody}

Cortical neuronal cultures were fixed with $4 \%$ paraformaldehyde in $0.1 \mathrm{M}$ phosphate-buffered saline (PBS) for $30 \mathrm{~min}$ and rinsed three times with PBS. Nonspecific sites were blocked, and cells were then rinsed two times with $1 \%$ normal goat serum (NGS) and $1 \%$ bovine serum albumin (BSA) in PBS for 10 min. Cultures were incubated with rabbit polyclonal MAP-2 (Chemicon) (dilution of 1:500 with $1 \% \mathrm{NGS} / 1 \% \mathrm{BSA}$ in PBS) overnight at $4^{\circ} \mathrm{C}$. Secondary antibody (Cy3-conjugated goat anti-rabbit IgG $(1: 500))$ was incubated for $60 \mathrm{~min}$ at room temperature in $1 \% \mathrm{NGS}+1 \%$ BSA in PBS. After washing, images were captured using a Leica TCS-NT microscope.

\section{Preparation of Neuronal Cell Lysates}

Following treatments in culture, cells were washed in PBS and collected in ice-cold lysis buffer $(250 \mathrm{mM}$ sucrose, $50 \mathrm{mM}$ Tris- $\mathrm{HCl}, \mathrm{pH} 7.5,25 \mathrm{mM} \mathrm{KCl}, 0.5 \mathrm{mM}$ phenylmethylsulfonyl fluoride, $0.9 \mathrm{mM}$ sodium butyrate, $1.0 \mathrm{mM}$ sodium orthovanadate, and $1 \%$ protease inhibitor cocktail, Sigma). Protein concentration was determined by the bicinchoninic acid method (BCA Protein Assay Kit, Sigma).

\section{Western Blot Analysis of Apoptotic Markers}

Equal amounts of protein were resolved in SDS-polyacrylamide gels and transferred electrophoretically onto a nitrocellulose membrane (Bio-Rad). Membranes were blocked for $1 \mathrm{~h}$ in TBST (10 mM Tris- $\mathrm{HCl}, \mathrm{pH} 8.0,138 \mathrm{mM}$ $\mathrm{NaCl}, 2.7 \mathrm{mM} \mathrm{KCl}$, and $0.05 \%$ Tween 20 ) and $5 \%$ nonfat milk and incubated overnight with anti-sera directed against cleaved caspase-3 (1:200; Santa Cruz Biotech), Bax (1:250; Santa Cruz Biotech.), Bcl-2 (1:250; Santa Cruz Biotech), Bcl-xl (1:500; Santa Cruz Biotech), or $\beta$-actin ( $1: 250$; Sigma). After washing with TBST, the membranes were incubated for $1 \mathrm{~h}$ with horseradish peroxidaseconjugated anti-rabbit or anti-mouse anti-sera in TBST and $3 \%$ nonfat milk. The membranes were washed again with TBST, and proteins were visualized by enhanced chemiluminescence. The optical density of each band was determined using Quantity One software (Bio-Rad) after normalizing to the expression of $\beta$-actin. 


\section{Caspase-3 Activity Assay}

Caspase-3 activity was measured spectrophotometrically using the substrate $\mathrm{N}$-acetyl-Asp-Glu-Val-Asp-p-nitroanilide (DEVD-pNa) in cortical homogenates according to the manufacturer's protocol (Caspase-3 Cellular Activity Assay Kit, Calbiochem, San Diego, CA). Specific activity of DEVDpNa cleavage for each sample was calculated by measuring the slope of the linear portion of the absorbance $v s$ time graph, and expressed as $\mathrm{pmol} \mathrm{pNa} / \mathrm{min} / \mathrm{mg}$ total protein.

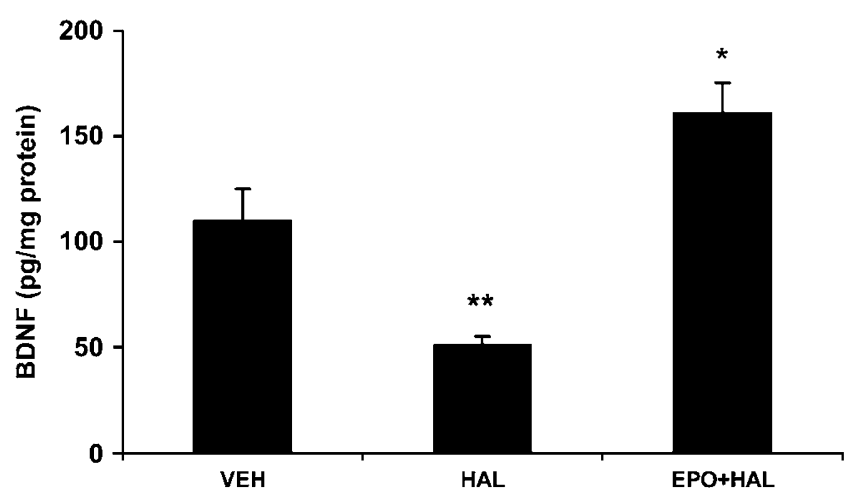

Figure I Co-treatment with rhEPO prevents haloperidol (HAL)induced reduction in brain-derived neurotrophic factor (BDNF) protein levels in rat frontal cortex. Rats were treated daily for 6 weeks with vehicle (VEH), HAL $(2 \mathrm{mg} / \mathrm{kg})$ or $\mathrm{HAL}+500 \mathrm{U} / \mathrm{kg} \mathrm{rhEPO}(\mathrm{HAL}+\mathrm{EPO})$ through drinking water. Values are mean $\pm \mathrm{SE}(n=5$ rats). $* p<0.05$ vs $\mathrm{VEH}$ and *** $<0.0$ I vs VEH as well as EPO + HAL; ANOVA followed by post hoc Dunnett's multiple comparison test.

\section{Statistical Analysis}

Results were expressed as means \pm SEM of five replicates of the same treatment and from 2 to 3 experiments done at different times using different sets of animals. The effect of different treatments was analyzed using a one-way analysis of variance (ANOVA) followed by post hoc Dunnett's multiple comparison test. A $p$-value of $<0.05$ was considered to be significant.

\section{RESULTS}

\section{In Vivo Studies in Rats}

rhEPO prevents $H A L$-induced decrease in BDNF levels in rat cerebral cortex. Continuous $\mathrm{HAL}$ treatment for 6 weeks significantly decreased BDNF protein levels compared to vehicle treatment (Figure $1 ; \mathrm{F}=20.113, \mathrm{df}=$ $2,30, p=0.002)$. EPO co-treatment prevented the HALassociated decrease in the BDNF protein levels $(p<0.001 v s$ HAL) and also significantly increased BDNF levels above vehicle treatment $(p<0.05 v s$ vehicle).

rhEPO prevents HAL-induced changes in apoptotic markers in rat cerebral cortex. The levels of Bcl-xl protein, an antiapoptotic marker, were significantly decreased after HAL treatment (Figure $2 \mathrm{a} ; \mathrm{F}=16.441, \mathrm{df}=2,30, p=0.004$ ) and were unchanged or slightly increased with rhEPO cotreatment (Figure 2a; EPO + HAL) as compared to vehicletreated rats. However, the levels of another antiapoptotic marker, Bcl-2 (Figure 2b), and the apoptotic marker, Bax protein (Figure 2c), did not change with either HAL treatment alone or with rhEPO co-treatment (EPO + HAL). a

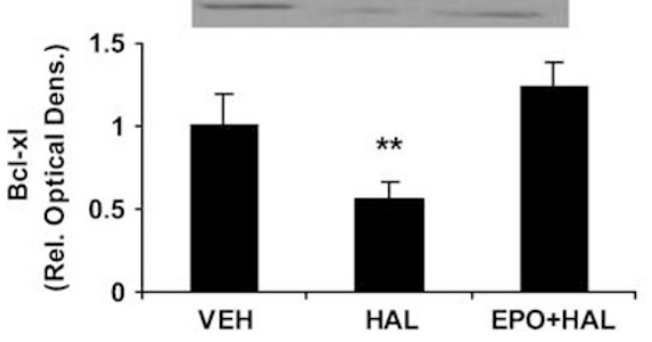

C

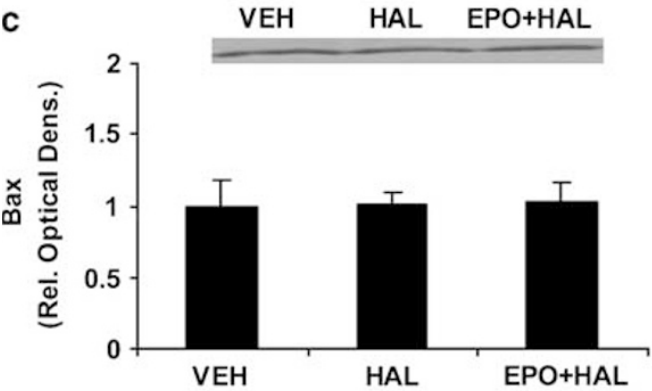

b
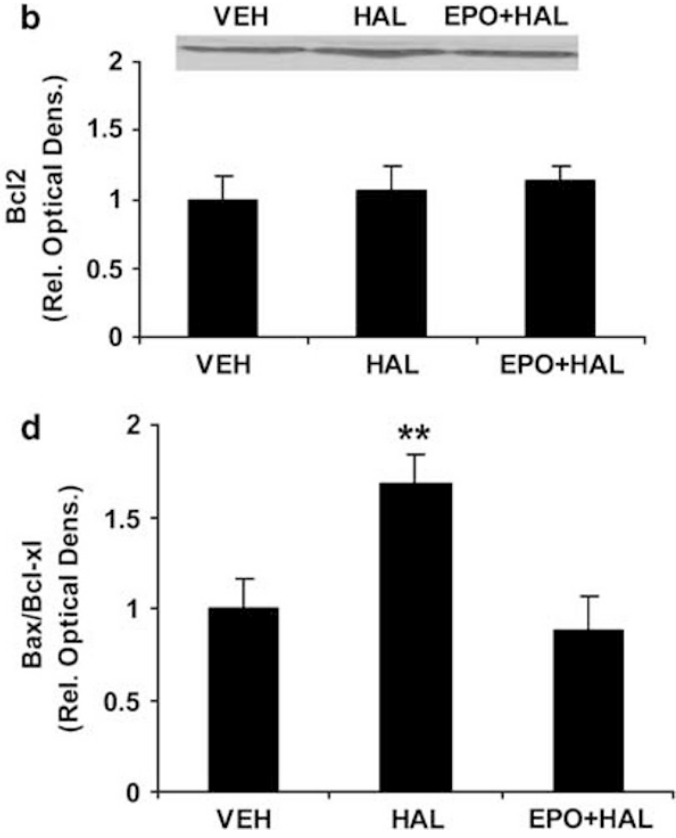

Figure 2 Effect of haloperidol (HAL) or $\mathrm{HAL}+$ rhEPO on levels of apoptotic markers in rat frontal cortex (a) $\mathrm{Bcl}-\mathrm{xl}$, (b) $\mathrm{Bcl}$, (c) $\mathrm{Bax}$, and (d) $\mathrm{Bax} / \mathrm{Bcl}-\mathrm{xl}$ ratio. The upper panels in (a), (b), and (c) show the autoradiogram of respective proteins from rats treated daily for 6 weeks with vehicle (VEH), HAL $(2 \mathrm{mg} / \mathrm{kg})$, or HAL $+500 \mathrm{U} / \mathrm{kg}$ rhEPO (HAL + EPO) through drinking water. The lower panels represent optical density values normalized to VEH-treated controls. $\beta$-Actin was used as a protein loading control (not shown). Values are mean $\pm \mathrm{SE}$ ( $n=5$ rats). *** $<0.0$ I vs VEH; ANOVA followed by post hoc Dunnett's multiple comparison test. 
As a result, the $\mathrm{Bax} / \mathrm{Bcl}-\mathrm{xl}$ ratio, indicative of increased apoptosis, was significantly increased in HAL-treated cortex (Figure 2d; $\mathrm{F}=10.85, \mathrm{df}=2,30, p=0.003$ ), whereas rhEPO co-treatment maintained the ratio to values in vehicletreated cortex samples.

rhEPO prevents HAL-induced changes in caspase- 3 protein levels and enzymatic activity in rat cerebral cortex. The level of cleaved caspase- 3 protein determined by western blot analysis was very low in the vehicle-treated samples (Figure 3a; VEH). However, this increased significantly (by 65\%) after 6 weeks of HAL treatment (Figure 3a; $\mathrm{HAL} ; \mathrm{F}=10.636, \mathrm{df}=2,30, p=0.011)$. rhEPO co-treatment markedly prevented the increase of caspase-3, which did not differ from the VEH-treated levels.

The enzymatic activity of caspase- 3 was also measured in cortical samples from rats treated with $\mathrm{HAL}$ alone or in combination with rhEPO. HAL treatment for 6 weeks induced a significant increase (Figure 3b; HAL; $p<0.05 v s$ $\mathrm{VEH}$ ) in caspase- 3 activity. The specific activity of caspase- 3 was $\sim 230 \%$ higher in HAL compared to VEH-treated rats. EPO prevented the increase in caspase- 3 activity associated with HAL treatment (Figure 3b; EPO + HAL), which was significantly lower $(p<0.05)$ than HAL but not statistically higher than $\mathrm{VEH}$.

\section{In Vitro Studies}

rhEPO co-treatment prevents the primary cortical neurons from $H A L$-induced cell death. Figure 4a shows the dosedependent effect of HAL (HAL10, HAL50, and HAL100) on neuronal cell survival and indicates that $24 \mathrm{~h}$ exposure of $50 \mu \mathrm{M} \mathrm{HAL}$ (HAL50) induced approximately $50 \%$ of neuronal death $(\mathrm{F}=35.665, \mathrm{df}=5,36, p<0.001)$. Cotreatment with $30 \mathrm{pM}$ of rhEPO (EPO30 + HAL50) significantly increased $(p<0.001$ vs HAL50) the neuronal survival against HAL toxicity. A lower dose $(3 \mathrm{pM})$ of rhEPO (EPO3 + HAL50) showed a smaller protective effect.

Figure $4 \mathrm{~b}$ shows representative photomicrographs of cortical neurons in culture with various treatments. The untreated cells (CON) appeared as healthy neurons with well-established neurite outgrowth. HAL treatment $(50 \mu \mathrm{M})$ for $24 \mathrm{~h}$ resulted in massive loss of neurites and shrinkage or loss of cell bodies. rhEPO-treated cells (EPO) appeared very healthy, with large-size neuronal cell bodies even compared to CON. rhEPO co-treatment (EPO + HAL) substantially protected the cellular morphology from HAL toxicity.

rhEPO prevents HAL-induced decrease in BDNF expression. Exposure of primary cortical neurons to $50 \mu \mathrm{M} \mathrm{HAL}$ for $24 \mathrm{~h}$ significantly decreased the level of BDNF protein
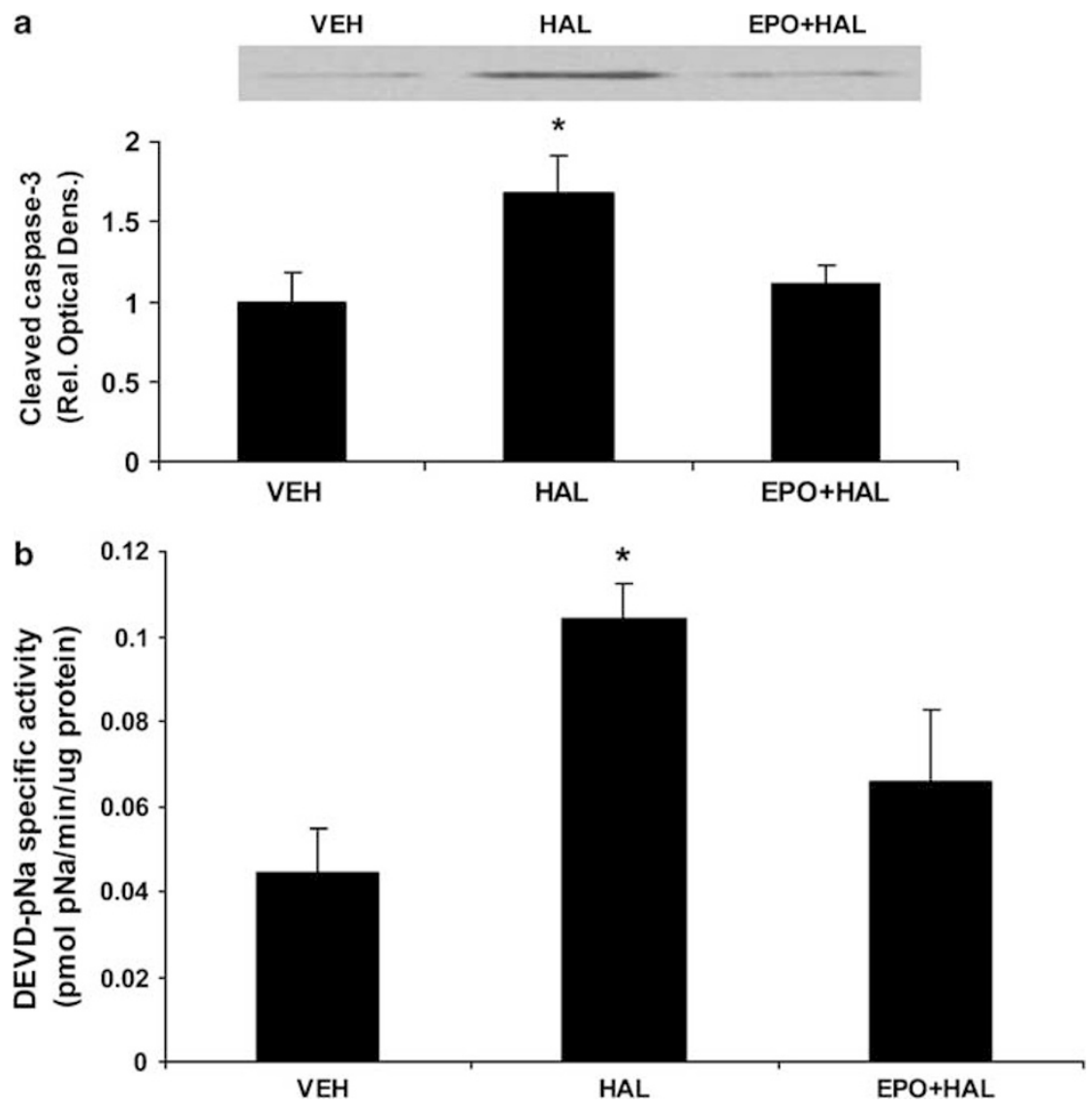

Figure 3 Effect of haloperidol (HAL) or HAL + rhEPO on (a) cleaved caspase-3 protein levels and (b) caspase-3-like enzymatic activity in rat frontal cortex. The upper panel in (a) shows the representative autoradiogram of cleaved caspase-3 from rats treated daily for 6 weeks with vehicle (VEH), HAL $(2 \mathrm{mg} / \mathrm{kg})$ or HAL $+500 \mathrm{U} / \mathrm{kg}$ rhEPO (HAL + EPO) through drinking water. Bar graphs represent OD (a) and activity (b) values normalized to VEH-treated controls. $\beta$-Actin was used as a protein loading control (not shown). Values are mean $\pm \mathrm{SE}(n=5$ rats). $* p<0.05$ vs VEH; ANOVA followed by post hoc Dunnett's multiple comparison test. 

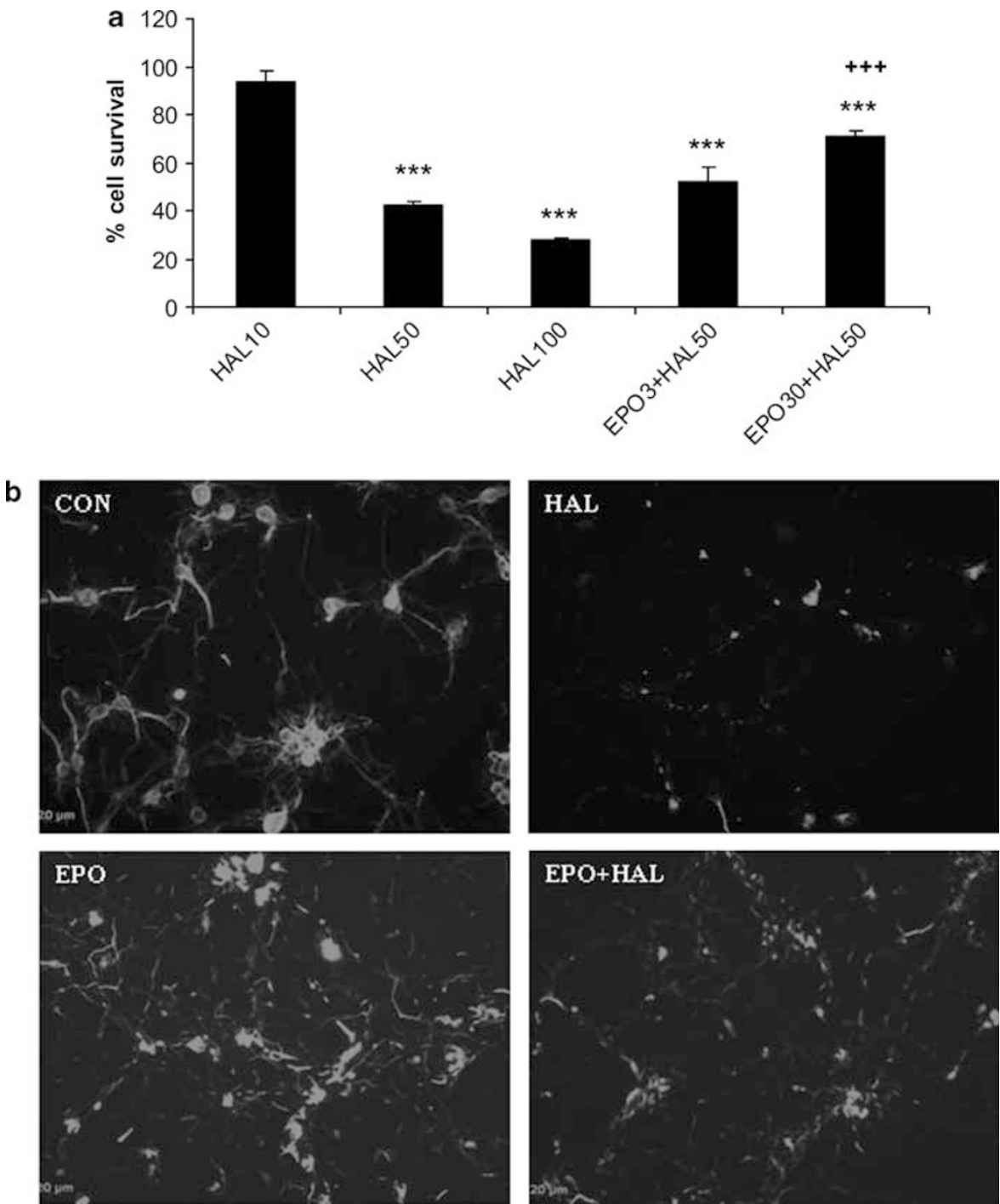

Figure 4 Erythropoietin (EPO) protects cortical neurons from haloperidol (HAL)-induced cell death. Cortical neurons were preincubated for $24 \mathrm{~h}$ with 3 and $30 \mathrm{pM}$ concentrations rhEPO, and then exposed to 10,50, and $100 \mu \mathrm{m}$ concentrations of HAL (HALI0, HAL50, and HALI 00, respectively) for 24 h. MTT assay was performed to test the cell viability. (a) EPO (30 pM, EPO30), but not $3 \mathrm{pM} \mathrm{EPO} \mathrm{(EPO3),} \mathrm{significantly} \mathrm{protected} \mathrm{cortical} \mathrm{neurons} \mathrm{from} \mathrm{HAL}$ toxicity. Values are mean \pm SE of five independent experiments. ${ }^{*} * * * 00.00$ I vs control $(100 \%)$ and ${ }^{++}{ }^{+} p<0.0$ I vs HAL50; ANOVA followed by post hoc Dunnett's multiple comparison test. (b). Representative photographs of cortical neurons stained with MAP2. The treatment groups are neurons treated with vehicle $(\mathrm{CON}), 50 \mu \mathrm{M} \mathrm{HAL}, 30 \mathrm{pM}$ rhEPO (EPO), or preincubation with $30 \mathrm{pM}$ rhEPO for $24 \mathrm{~h}$ and then treated with $50 \mu \mathrm{M} H \mathrm{AL}$ for next $24 \mathrm{~h}$ $(\mathrm{EPO}+\mathrm{HAL})$

(Figure 5; $\mathrm{F}=73.016, \mathrm{df}=3,36, p<0.001$ ) as compared to untreated cells. rhEPO $(30 \mathrm{pM})$ alone was able to increase the BDNF levels $(p<0.05)$ relative to untreated cells. However, rhEPO co-treatment prevented the HAL-associated decrease in BDNF protein levels $(p<0.001 v s$ HAL) and also significantly increased BDNF levels above the levels in the untreated cells $(p<0.001 v s$ vehicle).

Role of BDNF in rhEPO-induced neuroprotection against HAL-induced cell death. The role of BDNF in rhEPOinduced neuroprotection against HAL-induced neuronal cell death was investigated in primary cortical neurons. Neurons were exposed for $24 \mathrm{~h}$ to $30 \mathrm{pM}$ rhEPO in the presence or absence of a neutralizing anti-BDNF antibody and then challenged with $50 \mu \mathrm{M}$ HAL (Figure 6). HAL treatment reduced cell survival to $\sim 50 \%$ (Figure 6 , lane 1 ;
$\mathrm{F}=41.64, \mathrm{df}=5,60, p<0.001$ vs control, $100 \%)$. However, co-treatment with anti-BDNF IgG further decreased the cell survival (Figure 6, lane 2) but IgY (Figure 6, lane 3) did not. Preexposure of neurons for $24 \mathrm{~h}$ to $30 \mathrm{pM}$ rhEPO significantly increased the number of surviving neuronal cells (Figure 6, lane 4; $p<0.001 v s \mathrm{HAL}$ ), but this rhEPO survival effect was significantly prevented by $15 \mu \mathrm{g} / \mathrm{ml}$ anti-BDNF antibody (Figure 6 , lane $5 ; p<0.001$ ) indicating that rhEPO protection is mediated through associated increase in BDNF. Control IgY $(15 \mu \mathrm{g} / \mathrm{ml})$ did not affect EPO-induced neuroprotection or HAL-induced neuronal death (Figure 6, lane 6).

rhEPO prevents HAL treatment-induced decrease in Bcl-xl protein levels. Exposure of primary cortical neurons to $50 \mu \mathrm{M}$ HAL for $24 \mathrm{~h}$ significantly decreased the protein level 


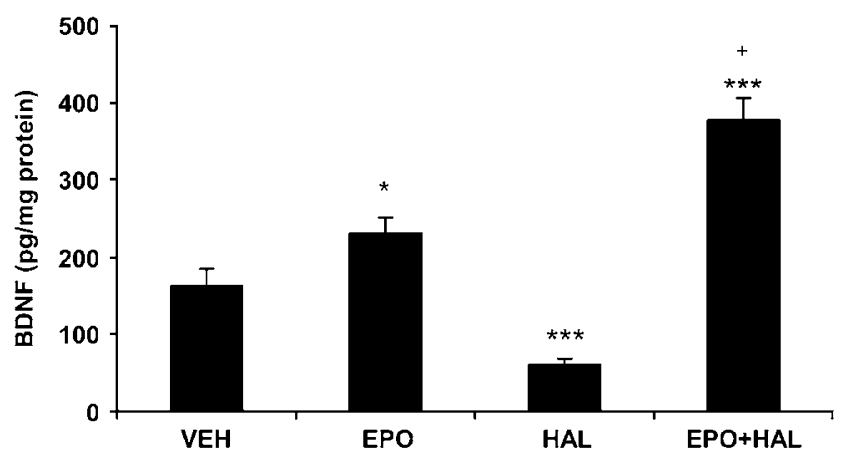

Figure 5 rhEPO prevents haloperidol (HAL)-induced reduction in brainderived neurotrophic factor (BDNF) protein levels in cortical neurons. Cortical neurons were preincubated for $24 \mathrm{~h}$ with $30 \mathrm{pM}$ rhEPO, and then exposed to $50 \mu \mathrm{M}$ HAL for $24 \mathrm{~h}$. Histograms show the quantification of BDNF protein expressed as $\mathrm{pg} / \mathrm{mg}$ protein from neurons treated with vehicle (VEH), rhEPO (erythropoietin, EPO), HAL, or rhEPO plus HAL $(\mathrm{EPO}+\mathrm{HAL})$. Cell viability is expressed as percentage of that measured in vehicle-treated neurons. Values are mean $\pm S E$ of five independent experiments. ${ }^{*} p<0.05$ and ${ }^{*} * * * 00.001$ vs $\mathrm{VEH} ;{ }^{+} p<0.05$ vs EPO; ANOVA followed by post hoc Dunnett's multiple comparison test.

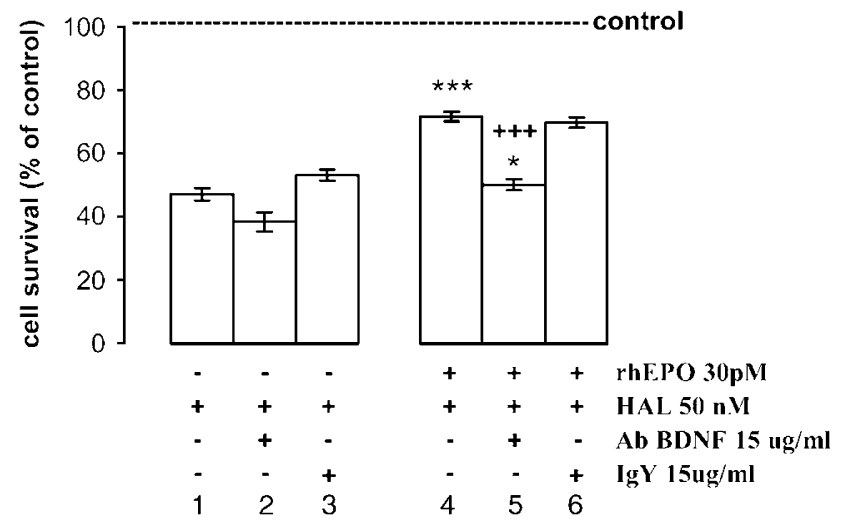

Figure 6 Role of brain-derived neurotrophic factor (BDNF) in EPOinduced neuroprotection against haloperidol (HAL) toxicity. Cortical neurons were preincubated $(+)$ or not $(-)$ for $24 \mathrm{~h}$ with $30 \mathrm{pM}$ rhEPO, $\mathrm{rhEPO}+15 \mu \mathrm{g} / \mathrm{ml}$ antibody against BDNF (Ab BDNF), or rhEPO + $15 \mu \mathrm{g} / \mathrm{ml}$ lgY and then exposed to $50 \mu \mathrm{M}$ HAL for $24 \mathrm{~h}$. MTT assay was performed to test the cell viability. EPO-induced neuroprotection against HAL was significantly prevented by Ab BDNF. Cell viability is expressed as percentage of that measured in vehicle-treated neurons (dotted line). Values are mean \pm SE of five independent experiments. $* * * * * 0.00$ I vs treatment I; $* p<0.05$ vs treatment 2 , and ${ }^{+++} p<0.00$ I vs treatment 4 ; ANOVA followed by post hoc Dunnett's multiple comparison test.

of $\mathrm{Bcl}-\mathrm{xl}$ (Figure 7, HAL; $\mathrm{F}=22.294, \mathrm{df}=2,18, p=0.003$ ). However, co-treatment of neurons with $30 \mathrm{pM}$ rhEPO significantly prevented the HAL-induced decrease in Bcl$\mathrm{xl}$ protein expression $(p=0.006 v s \mathrm{HAL})$. No change was observed in the levels of Bcl-2 and Bax either with HAL or with rhEPO co-treatment (data not shown).

\section{DISCUSSION}

This study is the first to report a neuroprotective effect of rhEPO against HAL-induced apoptosis and a possible underlying mechanism. This mechanism involves EPO-

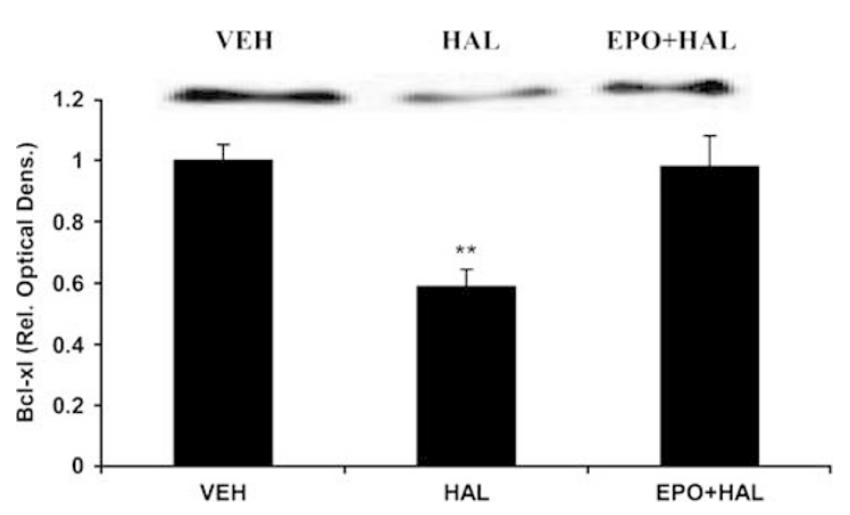

Figure 7 Effect of haloperidol (HAL) or $\mathrm{HAL}+$ rhEPO on $\mathrm{Bcl}-\mathrm{xl}$ levels in cortical neurons. Cortical neurons were preincubated for $24 \mathrm{~h}$ with $30 \mathrm{pM}$ $\mathrm{rhEPO}$, and then exposed to $50 \mu \mathrm{M} \mathrm{HAL}$ for $24 \mathrm{~h}$. The upper panel shows representative autoradiogram of $\mathrm{Bcl}-\mathrm{xl}$ from neurons treated with vehicle (VEH), HAL $(2 \mathrm{mg} / \mathrm{kg})$ or HAL $+500 \mathrm{U} / \mathrm{kg}$ rhEPO (HAL + EPO). The lower panel represents optical density values normalized to vehicle-treated controls. $\beta$-Actin was used as a protein loading control (not shown). Values are mean \pm SE of five independent experiments. $* * * 0.0$ I vs $V E H$ as well as EPO + HAL; ANOVA followed by post hoc Dunnett's multiple comparison test.

mediated increased levels of BDNF and changes in key BDNF-mediated antiapoptotic and apoptotic molecules in vivo and in vitro. The findings include: (1) rhEPO cotreatment with HAL was able to prevent the HAL-induced reduction in BDNF very effectively (a well-established antiapoptotic neurotrophic factor) protein levels in vivo and in vitro, (2) the neuroprotective role of BDNF in rhEPO was further confirmed by reduced neuronal survival by rhEPO when BDNF was neutralized by a specific antibody, (3) the HAL-induced decrease in BDNF levels was associated with a decrease in $\mathrm{Bcl}-\mathrm{xl}$ levels and an increase in caspase-3 levels, which were prevented by rhEPO cotreatment, and (4) the Bax/Bcl-xl ratio was increased with HAL treatment, an effect that was normalized by rhEPO co-treatment.

Our data are consistent with previous reports that HAL has cytotoxic effects in vivo and in vitro in various cell types, including primary neurons (Behl et al, 1995; Sagara, 1998; Noh et al, 2000). A number of mechanisms have been suggested for HAL-induced cytotoxicity, including necrotic and apoptotic mechanisms. The increased caspase- 3 activity in cultured neurons continuously exposed to HAL for $24 \mathrm{~h}$ is consistent with the earlier reports in rats (Ukai et al, 2004; Jarskog et al, 2007). Some studies have reported a caspase-independent pathway-mediated cell death by HAL (Wei et al, 2006; Crawford and Bowen, 2002). In the present study we observed (in addition to an increase in caspase-3 levels) a decrease in the antiapoptotic protein, Bcl-xl (thus resulting in a high $\mathrm{Bax} / \mathrm{Bcl}-\mathrm{xl}$ ratio), but no change in Bcl-2 levels in cortex after 45 days of HAL exposure in rats. Jarskog et al (2000) have also reported increased activity of caspase- 3 but no change in Bcl 2 in rat frontal cortex following 4 weeks of HAL administration. The increased $\mathrm{Bax} / \mathrm{Bcl}-\mathrm{xl}$ ratio has been also reported in rat hippocampus and caudate-putamen following $\mathrm{HAL}$ administration (Post et al, 2002).

EPO-induced neuroprotection is now well documented and thought to involve several mechanisms, one of which is 
the recruitment of molecules involved in neuroprotective signaling. Importantly, increased BDNF expression has been shown to mediate rhEPO-induced neuroprotection in various toxicity models (Dzietko et al, 2004; Viviani et al, 2005). In the present study, we found prevention of the HAL-induced reduction in BDNF protein levels by rhEPO co-treatment. This co-treatment approach is, therefore, important since earlier studies from our own and other laboratories have shown that long-term ( $>4$ weeks) HAL treatment causes reduction in BDNF levels (Pillai et al, 2006; Angelucci et al, 2000; Dawson et al, 2001) and EPO levels (Pillai and Mahadik, 2006) in rat brain. The argument that the neuroprotective role of rhEPO against HAL-induced cell death (in our study) was likely mediated via its effects on BDNF was supported by the reduced cortical neuronal cell survival induced by a specific neutralizing BDNF antibody.

Although the mechanism(s) underlying rhEPO-mediated neuroprotection are likely complex, one possibility involves the activation of PI3K-Akt to limit neuronal apoptosis (Maiese et al, 2004). Akt may then phosphorylate cAMP responsive element-binding protein (CREB), leading to increased BDNF promoter activity and gene expression (Hayes et al, 1997; Shieh and Ghosh, 1999; Zhang et al, 2006). In a separate study, we have reported that HAL exposure of cortical neuronal cultures reduced the Akt activation and pretreatment with rhEPO maintained the levels of activated Akt (Pillai et al, 2007a). Akt is also known to induce the expression of survival genes such as $\mathrm{Bcl}-2$ and Bcl-xl, by activating CREB and nuclear factor- $\kappa B$ (Downward, 2004). Though the ability of rhEPO to maintain BDNF levels may limit several adverse cellular effects of HAL, including a reduction in brain glutathione levels, decreased antioxidant enzyme expression, enhanced oxidative stress (Behl et al, 1995; Pillai et al, 2007b; Sagara, 1998; Shivakumar and Ravindranath, 1992; Yokoyama et al, 1998), and changes in cholinergic neuronal markers (Mahadik et al, 1988; Terry et al, 2003) since BDNF has already been found to prevent changes in these molecules (Mattson et al, 1995).

We selected 6 weeks of HAL exposure in this study as the chronic treatment period in rats to simulate the chronic continuous treatment in patients (ie 6 weeks in rats with a lifespan of approximately 35 months equals $>3$ years in humans with $>70$ years of lifespan). Such a time period of HAL exposure in humans has been associated with a broad range of adverse neuropathological (basal ganglia and diffuse loss of dendritic and synaptic loss) and neurobehavioral (extrapyramidal symptoms, tardive dyskinesia) effects (Cadet and Lohr, 1989; Jeste and Wyatt, 1982; Casey, 1985). We selected the $2.0 \mathrm{mg} / \mathrm{kg} / \mathrm{day}$ dose of HAL in our studies since this dose was previously found to establish clinically relevant (Baldessarini et al, 1988) steadystate plasma levels in the rat (Terry et al, 2007). It is also important to point out that under similar dosing conditions the levels of HAL were reported to be 10 times higher in the brain than plasma levels (Kornhuber et al, 2006). Also, the half-lives for elimination from brain were 7.9 as opposed to $<24 \mathrm{~h}$ from the plasma. The concentration of HAL used in cultures was established for optimum time and effect.

In conclusion, the findings of this study may have considerable clinical relevance based on the important role of BDNF in schizophrenia and the reported reductions in brain BDNF levels in rodent studies with long-term antipsychotic treatment (Pillai et al, 2006). Therefore, sustained or increased brain BDNF by exogenous rhEPO co-treatment has the potential to prevent and/or reverse neuropathological events in schizophrenia (Glantz et al, 2006). In support of this possibility, a recent clinical add-on therapy, rhEPO with antipsychotic medication, showed significant improvement in cognitive function in chronic schizophrenia patients (Ehrenreich et al, 2007). In addition, rhEPO has therapeutic advantages over other neurotrophic factors in terms of delivery to their target cells in the brain and clinical tolerability (Abicht and Lochmuller, 1999; Horina et al, 1991). Although there are some concerns regarding the hematopoietic activity of rhEPO, derivatives of rhEPO are being developed that have potent neuroprotective activity with no hematopoietic activity (Erbayraktar et al, 2003).

\section{ACKNOWLEDGEMENTS}

The work was supported partly by NIH/NIMH grant (MH 066233 to AVT).

\section{DISCLOSURE/CONFLICT OF INTEREST}

The author(s) declare that except for income received from my primary employer no financial support or compensation has been received from any individual or corporate entity over the past 3 years for research or professional service and there are no personal financial holdings that could be perceived as constituting a potential conflict of interest.

\section{REFERENCES}

Abicht A, Lochmuller H (1999). Technology evaluation: CRIB (CNTF delivery) Cyto Therapeutics Inc. Curr Opin Mol Ther 1: 645-650.

Alleva E, Della Seta D, Cirulli F, Aloe L (1996). Haloperidol treatment decreases nerve growth factor levels in the hypothalamus of adult mice. Prog Neuropsychopharmacol Biol Psychiatry 20: 483-489.

Angelucci F, Aloe L, Gruber SH, Fiore M, Mathe AA (2000). Chronic antipsychotic treatment selectively alters nerve growth factor and neuropeptide $\mathrm{Y}$ immunoreactivity and the distribution of choline acetyltransferase in rat brain regions. Int $J$ Neuropsychopharmacol 3: 13-25.

Bai O, Zhang H, Li XM (2004). Antipsychotic drugs clozapine and olanzapine upregulate bcl-2 mRNA and protein in rat frontal cortex and hippocampus. Brain Res 1010: 81-86.

Baldessarini RJ, Cohen BM, Teicher MH (1988). Significance of neuroleptic dose and plasma level in the pharmacological treatment of psychoses. Arch Gen Psychiatry 45: 79-91.

Behl C, Rupprecht R, Skutella T, Holsboer F (1995). Haloperidolinduced cell death - mechanism and protection with vitamin $\mathrm{E}$ in vitro. Neuroreport 7: 360-364.

Bernaudin M, Bellail A, Marti HH, Yvon A, Vivien D, Duchatelle I et al (2000). Neurons and astrocytes express EPO mRNA: oxygen-sensing mechanisms that involve the redox-state of the brain. Glia 30: 271-278.

Bernaudin M, Marti HH, Roussel S, Divoux D, Nouvelot A, MacKenzie ET et al (1999). A potential role for erythropoietin in focal permanent cerebral ischemia in mice. J Cereb Blood Flow Metab 19: 643-651. 
Brines ML, Ghezzi P, Keenan S, Agnello D, de Lanerolle NC, Cerami C et al (2000). Erythropoietin crosses the blood-brain barrier to protect against experimental brain injury. Proc Natl Acad Sci USA 97: 10526-10531.

Buckley PF, Mahadik SP, Pillai A, Terry Jr AV (2007). Neurotrophins and schizophrenia. Schizophr Res 94: 1-11.

Bymaster FP, Hemrick-Luecke SK, Perry KW, Fuller RW (1996). Neurochemical evidence for antagonism by olanzapine of dopamine, serotonin, a1-adrenergic and muscarinic receptors in vivo in rats. Psychopharmacology (Berl) 124: 87-94.

Cadet JL, Lohr JB (1989). Possible involvement of free radicals in neuroleptic-induced movement disorders. Evidence from treatment of tardive dyskinesia with vitamin E. Ann NY Acad Sci 570: 176-185.

Casey DE (1985). Behavioral effects of long-term neuroleptic treatment in Cebus monkeys. Psychopharmacology 2: 211-216.

Crawford KW, Bowen WD (2002). Sigma-2 receptor agonists activate a novel apoptotic pathway and potentiate antineoplastic drugs in breast tumor cell lines. Cancer Res 62: 313-322.

Dawson NM, Hamid EH, Egan MF, Meredith GE (2001). Changes in the pattern of brain-derived neurotrophic factor immunoreactivity in the rat brain after acute and subchronic haloperidol treatment. Synapse 39: 70-81.

Dhandapani KM, Hadman M, De Sevilla L, Wade MF, Mahesh VB, Brann DW (2003). Astrocyte protection of neurons: role of transforming growth factor-beta signaling via a c-Jun-AP-1 protective pathway. J Biol Chem 278: 43329-43339.

Didriksen M (1995). Effects of antipsychotics on cognitive behavior in rats using the delayed non-match to position paradigm. Eur J Pharmacol 28: 241-250.

Downward J (2004). PI 3-kinase, Akt and cell survival. Semin Cell Dev Biol 15: 177-182.

Dzietko M, Felderhoff-Mueser U, Sifringer M, Krutz B, Bittigau P, Thor F et al (2004). Erythropoietin protects the developing brain against $N$-methyl-D-aspartate receptor antagonist neurotoxicity. Neurobiol Dis 15: 177-187.

Ehrenreich H, Hinze-Selch D, Stawicki S, Aust C, Knolle-Veentjer S, Wilms $S$ et al (2007). Improvement of cognitive functions in chronic schizophrenic patients by recombinant human erythropoietin. Mol Psychiatry 12: 206-220.

Erbayraktar S, Grasso G, Sfacteria A, Xie QW, Coleman T, Kreilgaard M et al (2003). Asialoerythropoietin is a nonerythropoietic cytokine with broad neuroprotective activity in vivo. Proc Natl Acad Sci USA 100: 6741-6746.

Glantz LA, Gilmore JH, Lieberman JA, Jarskog LF (2006). Apoptotic mechanisms and the synaptic pathology of schizophrenia. Schizophr Res 81: 47-63.

Hayes VY, Towner MD, Isackson PJ (1997). Organization, sequence and functional analysis of a mouse BDNF promoter. Brain Res Mol Brain Res 45: 189-198.

He J, Xu H, Yang Y, Zhang X, Li XM (2004). Neuroprotective effects of olanzapine on methamphetamine-induced neurotoxicity are associated with an inhibition of hyperthermia and prevention of Bcl-2 decrease in rats. Brain Res 1018: 186-192.

Horina JH, Schmid CR, Roob JM, Winkler HM, Samitz MA, Hammer HF et al (1991). Bone marrow changes following treatment of renal anemia with erythropoietin. Kidney Int 40: 917-922.

Jarskog LF, Gilmore JH, Glantz LA, Gable KL, German TT, Tong RI et al (2007). Caspase-3 activation in rat frontal cortex following treatment with typical and atypical antipsychotics. Neuropsychopharmacology 32: 95-102.

Jarskog LF, Gilmore JH, Selinger ES, Lieberman JA (2000). Cortical bcl-2 protein expression and apoptotic regulation in schizophrenia. Biol Psychiatry 48: 641-650.

Jarskog LF, Lieberman JA (2006). Neuroprotection in schizophrenia. J Clin Psychiatry 67: e09.
Jarskog LF, Selinger ES, Lieberman JA, Gilmore JH (2004). Apoptotic proteins in the temporal cortex in schizophrenia: high Bax/Bcl-2 ratio without caspase-3 activation. Am J Psychiatry 161: 109-115.

Jeste DV, Wyatt RJ (1982). Therapeutic strategies against tardive dyskinesia. Two decades of experience. Arch Gen Psychiatry 39: 803-816.

Kapur S, Arenovich T, Agid O, Zipursky R, Lindborg S, Jones B (2005). Evidence for onset of antipsychotic effects within the first $24 \mathrm{~h}$ of treatment. Am J Psychiatry 162: 939-946.

Kornhuber J, Wiltfang J, Riederer P, Bleich S (2006). Neuroleptic drugs in the human brain: clinical impact of persistence and region-specific distribution. Eur Arch Psychiatry Clin Neurosci 256: $274-280$.

Leucht S, Busch R, Hamann J, Kissling W, Kane JM (2005). Earlyonset hypothesis of antipsychotic drug action: a hypothesis tested, confirmed and extended. Biol Psychiatry 57: 1543-1549.

Lieberman JA, Tollefson G, Tohen M, Green AI, Gur RE, Kahn R et al (2003). Comparative efficacy and safety of atypical and conventional antipsychotic drugs in first-episode psychosis: a randomized, double-blind trial of olanzapine $v s$ haloperidol. Am J Psychiatry 160: 1396-1404.

Mahadik SP, Laev H, Korenovsky A, Karpiak SE (1988). Haloperidol alters rat CNS cholinergic system: enzymatic and morphological analyses. Biol Psychiatry 24: 199-217.

Maiese K, Li F, Chong ZZ (2004). Erythropoietin in the brain: can the promise to protect be fulfilled? Trends Pharmacol Sci 25: 577-583.

Marti HH (2004). Erythropoietin and the hypoxic brain. J Exp Biol 207: 3233-3242.

Mattson MP, Lovell MA, Furukawa K, Markesbery WR (1995). Neurotrophic factors attenuate glutamate-induced accumulation of peroxides, elevation of intracellular $\mathrm{Ca} 2+$ concentration, and neurotoxicity and increase antioxidant enzyme activities in hippocampal neurons. J Neurochem 65: 1740-1751.

Noh JS, Kang HJ, Kim EY, Sohn S, Chung YK, Kim SU et al (2000). Haloperidol-induced neuronal apoptosis: role of p38 and c-JunNH(2)-terminal protein kinase. J Neurochem 75: 2327-2334.

Parikh V, Khan MM, Mahadik SP (2004a). Olanzapine counteracts reduction of brain-derived neurotrophic factor and TrkB receptors in rat hippocampus produced by haloperidol. Neurosci Lett 356: 135-139.

Parikh V, Khan MM, Terry A, Mahadik SP (2004b). Differential effects of typical and atypical antipsychotics on nerve growth factor and choline acetyltransferase expression in the cortex and nucleus basalis of rats. J Psychiatr Res 38: 521-529.

Parikh V, Terry AV, Khan MM, Mahadik SP (2004c). Modulation of nerve growth factor and choline acetyltransferase expression in rat hippocampus after chronic exposure to haloperidol, risperidone, and olanzapine. Psychopharmacology (Berl) 172: 365-374.

Pillai A, Dhandapani KM, Buckley PF, Mahadik SP (2007a). Do neurotrophins have therapeutic potential in schizophrenia? Erythropoietin prevents haloperidol toxicity through increased expression of BDNF. Schizophr Bull 33: 203.

Pillai A, Mahadik SP (2006). Differential effects of haloperidol and olanzapine on the expression of erythropoietin and its receptor in rat hippocampus and striatum. J Neurochem 98: 1411-1422.

Pillai A, Parikh V, Terry Jr AV, Mahadik SP (2007b). Long-term antipsychotic treatments and crossover studies in rats: differential effects of typical and atypical agents on the expression of antioxidant enzymes and membrane lipid peroxidation in rat brain. J Psychiatr Res 41: 372-386.

Pillai A, Sharma S, Mahadik SP (2005). Modulation of BDNF levels by antipsychotics regulates their temporal effects on neurogenesis in hippocampus. Biol Psychiatry 57: $201 \mathrm{~S}$.

Pillai A, Terry Jr AV, Mahadik SP (2006). Differential effects of long-term treatment with typical and atypical antipsychotics on 
NGF and BDNF levels in rat striatum and hippocampus. Schizophr Res 82: 95-106.

Post A, Rucker M, Ohl F, Uhr M, Holsboer F, Almeida OF et al (2002). Mechanisms underlying the protective potential of alphatocopherol (vitamin E) against haloperidol-associated neurotoxicity. Neuropsychopharmacology 26: 397-407.

Sagara Y (1998). Induction of reactive oxygen species in neurons by haloperidol. J Neurochem 71: 1002-1012.

Sakanaka M, Wen TC, Matsuda S, Masuda S, Morishita E, Nagao M et al (1998). In vivo evidence that erythropoietin protects neurons from ischemic damage. Proc Natl Acad Sci USA 95: 4635-4640.

Shieh PB, Ghosh A (1999). Molecular mechanisms underlying activity-dependent regulation of BDNF expression. J Neurobiol 41: 127-134.

Shivakumar BR, Ravindranath V (1992). Oxidative stress induced by administration of the neuroleptic drug haloperidol is attenuated by higher doses of haloperidol. Brain Res 595: 256-262.

Shoval G, Weizman A (2005). The possible role of neurotrophins in the pathogenesis and therapy of schizophrenia. Eur Neuropsychopharmacol 15: 319-329.

Siren AL, Fratelli M, Brines M, Goemans C, Casagrande S, Lewczuk P et al (2001a). Erythropoietin prevents neuronal apoptosis after cerebral ischemia and metabolic stress. Proc Natl Acad Sci USA 98: 4044-4049.

Siren AL, Knerlich F, Poser W, Gleiter CH, Bruck W, Ehrenreich H (2001b). Erythropoietin and erythropoietin receptor in human ischemic/hypoxic brain. Acta Neuropathol (Berl) 101: 271-276.

Skarsfeldt T (1996). Differential effect of antipsychotics on place navigation of rats in Morris water maze. A comparative study between novel and reference antipsychotics. Psychopharmacology (Berl) 124: 126-133.

Spandou E, Soubasi V, Papoutsopoulou S, Karkavelas G, Simeonidou C, Kaiki-Astara A et al (2004). Erythropoietin prevents hypoxia/ischemia-induced DNA fragmentation in an experimental model of perinatal asphyxia. Neurosci Lett 366: 24-28.

Swartz MS, Perkins DO, Stroup TS, Davis SM, Capuano G, Rosenheck RA, CATIE Investigators et al (2007). Effects of antipsychotic medications on psychosocial functioning in patients with chronic schizophrenia: findings from the NIMH CATIE study. Am J Psychiatry 164: 428-436.

Terry Jr AV, Gearhart DA, Warner SE, Zhang G, Bartlett MG, Middlemore ML et al (2007). Oral haloperidol or risperidone treatment in rats: temporal effects on nerve growth factor receptors, cholinergic neurons, and memory performance. Neuroscience 146: 1316-1332.

Terry Jr AV, Hill WD, Parikh V, Evans DR, Waller JL, Mahadik SP (2002). Differential effects of chronic haloperidol and olanzapine exposure on brain cholinergic markers and spatial learning in rats. Psychopharmacology (Berl) 164: 360-368.

Terry Jr AV, Hill WD, Parikh V, Waller JL, Evans DR, Mahadik SP (2003). Differential effects of haloperidol, risperidone, and clozapine exposure on cholinergic markers and spatial learning performance in rats. Neuropsychopharmacology 28: 300-309.

Terry AV, Parikh V, Nasrallah HA, Mahadik SP (2004). Time dependent effects of haloperidol and ziprasidone on nerve growth factor, cholinergic neurons and spatial learning in rats. Biol Psychiatry 55: 47S.

Terry Jr AV, Mahadik SP (2007). Time dependent cognitive deficits associated with first and second generation antipsychotics: cholinergic dysregulation as a potential mechanism. J Pharmacol Exp Ther 320: 961-968.

Ukai W, Ozawa H, Tateno M, Hashimoto E, Saito T (2004). Neurotoxic potential of haloperidol in comparison with risperidone: implication of Akt-mediated signal changes by haloperidol. J Neural Transm 111: 667-681.

Viviani B, Bartesaghi S, Corsini E, Villa P, Ghezzi P, Garau A et al (2005). Erythropoietin protects primary hippocampal neurons increasing the expression of brain-derived neurotrophic factor. J Neurochem 93: 412-421.

Wei Z, Mousseau DD, Dai Y, Cao X, Li XM (2006). Haloperidol induces apoptosis via the sigma2 receptor system and Bcl-XS. Pharmacogenomics J 6: 279-288.

Yokoyama H, Kasai N, Ueda Y, Niwa R, Konaka R, Mori N et al (1998). In vivo analysis of hydrogen peroxide and lipid radicals in the striatum of rats under long-term administration of a neuroleptic. Free Radic Biol Med 24: 1056-1060.

Zhang F, Signore AP, Zhou Z, Wang S, Cao G, Chen J (2006). Erythropoietin protects CA1 neurons against global cerebral ischemia in rat: potential signaling mechanisms. J Neurosci Res 83: 1241-1251. 